carried out between September 1995 and May 1996.

Jacques Bouchard, director of military applications at the French Atomic Energy Commission, denies the claims of critics that the purpose of the tests is to develop better weapons, claiming that they are necessary to ensure that present weapons are functional and can be satisfactorily replaced.

"Nuclear weapons last only about 20 years and must be renewed as they age," he says. "This is not a question of improving performance or miniaturization; the weapons in question are more or less the same models as those of a few years ago."

Bouchard also says that at the time of the 1992 moratorium, France had not collected sufficient data to design good computer simulations of tests, and that the resumed testing shows France's commitment to a future complete test ban by allowing the completion of such simulations.

Meanwhile, the impact of the tests remains controversial. Critics such as Bruno Barillot, of the Centre of Documentation and research on Peace and Conflicts in Lyons, claim there is evidence of increased rates of cancer in the region after nuclear testing. (Government officials have responded to such suggestions by arguing that the cancer rates are now in line with those of industrialized countries.)

A report published in 1987 on the effects of underground testing on the atoll concluded that the risks of radioactive pollution in the short term were "negligible". But it added that the longer-term rsisk were more difficult to evaluate.

Despite the lack of any conclusive evidence of the risks, many scientists have spoken out against the decision to resume testing. They include at least one physicist - Michel Cribier - working at the Atomic Energy Commission, and several individual members of both the academy and the National Ethics Committee.

Critics point out that former President François Mitterrand used expert reports similar to those delivered to Chirac as grounds for not continuing testing. They say that this shows that the decision to resume testing was taken for political, and not scientific or technical, reasons.

One petition being circulated by Pierre Jaeglé and Alain Sureau of the University of Orsay acknowledges that experimentation is needed to reinforce simulation. But it says that this is a cyclical argument that can only be stopped by a political decision.

In addition to ethical and environmental arguments, some scientists say they are also concerned that the large sums of money necessary for the nuclear tests may lead to further reductions in the already limited funding for research for peaceful purposes.

Marianne Grunberg-Manago, the president of the academy, has also expressed disappointment that the academy was not consulted before the decision to resume testing was made.

Kimberly Carr

\title{
Balkan physics cruise shifts to dry land after protests
}

Munich. A high energy physics conference bringing together researchers from countries in the Balkan region has been taking place this week in the northeastern Italian town of Trieste, close to the border with the former Yugoslavia.

But earlier plans to hold the meeting on 'neutral' territory represented by a boat sailing around the Balkan area were abandoned after objections from some potential participants that this would have appeared insensitive to the political context in which it was taking place.

The so-called Four Seas conference still takes its name from the original plan, which was to hold it on board a ship cruising from Trieste to Burgas in Bulgaria across four seas - the Adriatic,

the Aegean, the

Marmara and the

Black Seas.

The meeting has been organized by Georges Charpak, formerly of the European Laboratory for Particle Physics (CERN), and winner of the 1992 Nobel prize for physics. He says

that the idea of the cruise was to provide a neutral venue which speakers could attend without compromising their national or political affiliations.

Before the violence that has accompanied the break-up of Yugoslavia, international summer schools in particle physics used to take place regularly in various Yugoslav cities, such as Sarajevo and Dubrovnik. Charpak says he wants the Four Seas conference to revive this tradition, which provided an important opportunity for contact between scientists in the various Balkan countries.

His original, somewhat idealistic, plan was for the cruise to make regular stops to pick up participants from ports in their own countries, in order to reduce the difficulties they might have otherwise experienced in travelling between countries in the region.

But some members of the conference's advisory committee objected to the plan. They claimed that the cruise could have been interpreted as a pleasure trip down the Adriatic coast, giving the impression that the physicists were insensitive to the conflicts raging on land.

The European Commission had already agreed to contribute up to ECU120,000 (US\$158,000) towards the conference. But Charpak, who reluctantly agreed last September to hold the conference on dry (and non-Balkan) land, says that additional sponsors, such as France's Centre d'Etudes Nucléaires at Saclay near Paris, could have been offended.

Even after the switch to Trieste, however, where the conference is being held at the International School for Advanced Studies, the organizers met substantial resistance to the concept that the meeting could be attended by any scientist in the region, regardless of country of origin.

Many potential participants refused to attend because they did not want to share a platform with a scientist from an enemy country. Despite his own war-time experiences as a member of the French resistance, Charpak says he had not expected to encounter such a violent reaction. "Even physicists not directly involved in the war hate each others' guts", he says.

Charpak says that some physicists from states in the former Yugoslavia refused to attend because they objected to the presence of a speaker from CERN whose father had played a role in the war that they found unacceptable. "It is a kind of craziness," he says. "Some physicists are already ideologically overtaken by the war."

Despite the difficulties, the conference has managed to attract 180 participants, more than half from the Balkan countries, which include Greece and Turkey, as well as several former communist states, such as Albania and Bulgaria. But Charpak says that the numbers from former Yugoslavian countries have been disappointingly low.

Speakers at the meeting included the Nobel prizewinner Carlo Rubbia. Charpak says that the Four Seas conference is planned to become an annual event - and that he eventually hopes that it will be able to take place on the four seas as originally planned.

Alison Abbott

\section{Polio pioneer Salk dies}

\section{San Diego. Jonas Edward Salk (right), who developed the first vaccine against poliomyel- itis and founded the scientifically and architecturally renowned Salk Institute in La Jolla, died on 23} June aged 80.

"We are extraordinarily saddened by the loss," said Francis Crick, Nobel prizewinner laureate and president of the Institute. "Few have made one discovery that has benefited humanity so greatly." $\square$ 